\title{
Analysis and definition of potential new areas for viticulture in the Azores (Portugal)
}

\author{
J. Madruga ${ }^{1}$, E. B. Azevedo ${ }^{1,2}$, J. F. Sampaio ${ }^{1}$, F. Fernandes ${ }^{2}$, F. Reis ${ }^{2}$, and J. Pinheiro ${ }^{1}$ \\ ${ }^{1}$ CITA_A, Research Center of Agrarian Sciences of the University of the Azores, \\ 9700-042 Angra do Heroísmo, Portugal \\ ${ }^{2}$ CCMMG, Research Center for Climate, Meteorology and Global Change, University of the Azores, \\ 9700-042 Angra do Heroísmo, Portugal
}

Correspondence to: J. Pinheiro (jpinheiro@uac.pt)

Received: 10 November 2014 - Published in SOIL Discuss.: 8 December 2014

Revised: 19 June 2015 - Accepted: 23 June 2015 - Published: 13 July 2015

\begin{abstract}
Vineyards in the Azores have been traditionally settled on lava field terroirs but the practical limitations of mechanization and high demand on man labor imposed by the typical micro parcel structure of these vineyards contradict the sustainability of these areas for wine production, except under government policies of heavy financial support. Besides the traditional vineyards there are significant areas in some of the islands whose soils, climate and physiographic characteristics suggest a potential for wine production that deserves to be the object of an assessment, with a view to the development of new vineyard areas offering conditions for better management and sustainability.

The landscape zoning approach for the present study was based in a geographic information system (GIS) analysis incorporating factors related to climate, topography and soils. Three thermal intervals referred to climate maturity groups were defined and combined with a single slope interval of $0-15 \%$ to exclude the landscape units above this limit. Over this resulting composite grid, the soils were then selectively cartographed through the exclusion of the soil units not fulfilling the suitability criteria.

The results show that the thermal interval of warmer conditions, well represented in the traditional terroir of Pico island, has practically no expression in the other islands. However, for the intermediate and the cooler classes, we could map areas of 5611 and 18115 ha respectively, fulfilling the defined soils and slope criteria, indicating thus the existence of some landscapes in the studied islands revealing adequate potential for future development of viticulture, although certainly demanding a good judgment on the better grape varieties to be adapted to those climatic conditions.
\end{abstract}

\section{Introduction}

Under the holistic concept of terroir, which deals with the influence of environmental factors on vine behavior and grape ripening, climate is recognized as the factor that exerts one of the most significant effects on the ability of a region to produce quality grapes (Jones, 2006).

It is also well accepted that geology and the particular soil conditions are of great importance in defining the characteristics and qualities of the wine as the final product (Mackenzie and Christy, 2005), in spite of the recognized difficulty of establishing and interpreting this relationship clearly.
Moreover, although it is known that the vine is adaptable to a wide diversity of soil types, it appears also that many of the world's most famous vineyards are installed in poor, shallow or rocky terrain (Van Leeuwen and Seguin, 2006) where no other crop would be grown in favorable conditions. Such is the case, which is almost extreme, of the vines planted in the lands of biscoito and lagido, the traditional names in the archipelago of the Azores to the cracked surfaces of basaltic lava fields of heterogeneous size ranging from gravel to blocks; this is a harsh environment for all forms of agriculture except for grape vines where the plants still manage 

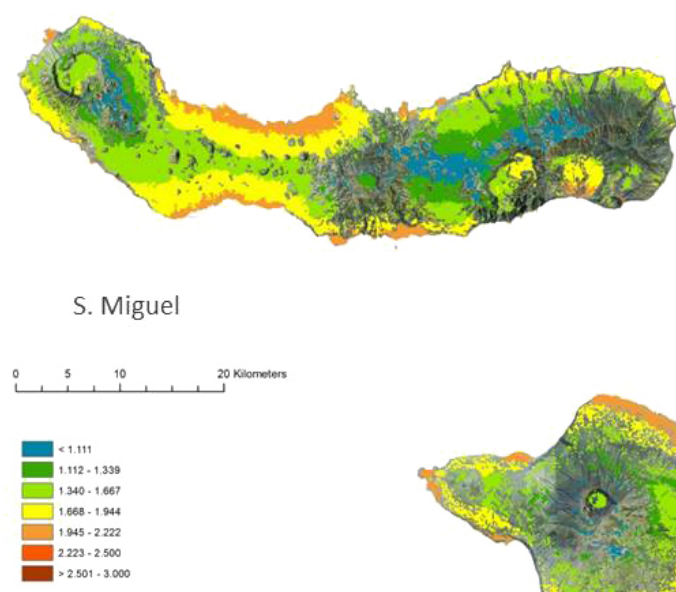

Growing Degree-Days

Winkler Scale ; April-October, base $10^{\circ} \mathrm{c}$
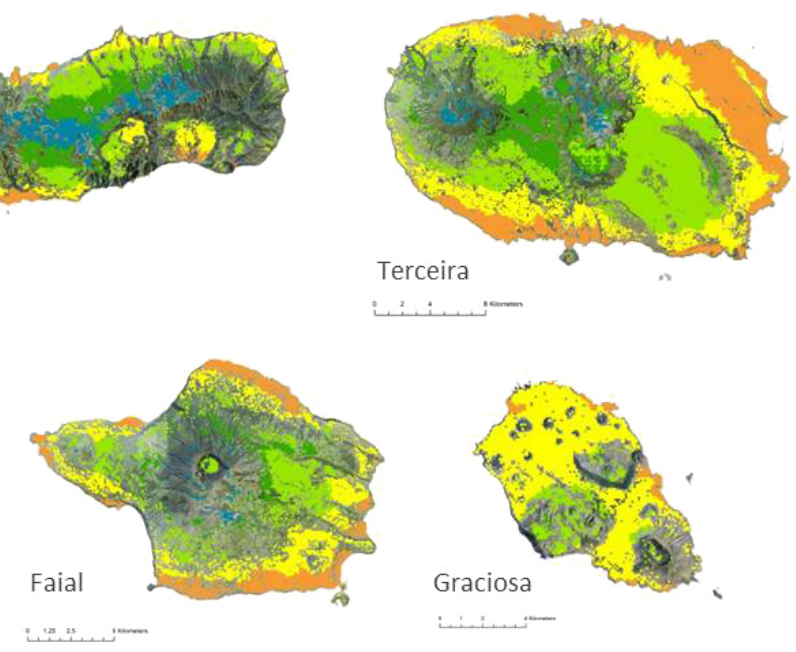

Figure 1. Winkler scale distribution for S. Miguel, Terceira, Faial and Graciosa islands of the Azores.

to survive and produce. This is mostly expressed in the landscape of the Pico island vineyard culture, recently classified as a UNESCO World Heritage Site (987 ha).

Due to the financial support measures implemented by the regional government of the Azores, the maintenance and recovery of abandoned areas of traditional vineyards within the limits of the classified area have recently gained a renewed interest by the land owners and wine producers. However, outside of these limits, there are vast areas with similar conditions where the ancient vineyards have been abandoned for a long time without any perspective of recovery, being presently colonized by invasive trees and shrubs species, predominantly the Pittosporum undulatum Vent. In fact, the practical limitations of mechanization and high demand on man labor imposed by the micro parcel structure of the vineyards aggravated by the absence of financial subsidies outside of the classified area make it impossible to admit the recovery of these areas for the wine production in present times.

Besides Pico island, where the costal landscape is dominated by lava fields of abandoned vineyards with the exception of the classified area, a few small spots also exist in some of the other islands of the archipelago, where in most cases the production has been partially abandoned as well.

Apart from this traditional Azorean model of terroir of recognized cultural value and where a few interesting wines have been produced, there are significant areas in some of the islands whose soils, climate and physiographic characteristics suggest a potential for wine production that deserves to be the object of an assessment, with a view to the development of new vineyard areas offering conditions for a better management and sustainability. We refer specifically to landscape units of the lower area of some islands, in many cases presently devoted to pasture where productivity tends to be marginal because it is strongly affected by water stress during the summer. Such areas, presenting gentle to moderate slopes and providing conditions to the mechanization of farming operations, comprise some well drained soils of the Andisol order (Soil Survey Staff, 2014).

In this preliminary study climatic, pedological and topographical characteristics of the landscape are considered based on GIS tools in order to define the distribution of the most representative landscape units with the greatest apparent potential for wine production in some islands of the Azores. It is not our objective to produce a detailed cartographic definition of vineyard suitability classes but rather to establish some basic criteria for prediction and identification of new areas from which representative sites can be depicted for experimental studies in a subsequent phase.

\section{Data and methodology}

The landscape zoning approach for the present study is that of the so-called "natural terroir units" (Laville, 1993; Priori et al., 2014) and was based on a Geographic Information System (GIS) analysis incorporating factors of climate and topography which was then combined with the soil mapping units fulfilling the suitable criteria concerning the soil properties taken as the most relevant for viticulture (Van Leeuwen et al., 2004; Deloire et al., 2005; Jones et al., 2004; Dutt et al., 1985).

In this work, the spatial climatic differentiation for viticulture is based on climate and/or maturity classes defined from the sum of the daily average temperatures that exceeds a base temperature of $10^{\circ} \mathrm{C}$ along the growing season, as expressed in growing degree days (GrDDs) concept and representing the potential for the region to ripen given varieties based upon heat accumulation. 

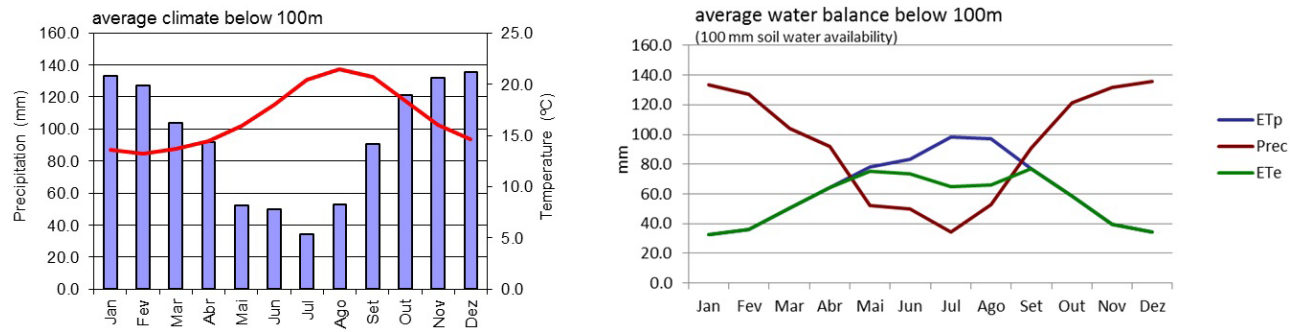

Figure 2. Normal climate and a typical sequential water balance at the littoral of the Azores Islands.

A first cartographic approach has been attempted (Fig. 1) using the full Winkler scale (Amerine and Winkler, 1944; Winkler et al., 1974) for the traditional April-October Period, allowing for comparisons with other wine regions of the northern hemisphere. However, those results when compared with the cartography of the geographical distribution of the traditional vineyards of the Azores Islands (Madruga et al., 2011), denoted an evident lack of resolution. The temperature of $278^{\circ} \mathrm{C}$ in each maturity grouping of the Winkler index was apparently excessive for the representation of the variability degree observed in the field at the lower altitudes of the islands, where grapevines can be grown in the Azores. Additionally, in the cartographic output of Fig. 1 the lower GDD maturity groupings of the Winkler scale (cool and temperate) were represented at altitudes where the general climatic conditions other than temperature, such as relative humidity, winds and cloudiness, are globally adverse to the grapevine growth and fruit maturation.

From this evidence, we implemented an alternative GDD criteria based in only three thermal classes, being the temperature of the maturity groupings narrowed to $200^{\circ} \mathrm{C}$, defined however for the same April-October period as the Winkler index.

For the establishment of these three classes, the thermal conditions found in the traditional vineyards mainly of Pico and Terceira islands, were taken as the baseline reference and from those the accumulating growing degree-days were defined in the following intervals: I: $1600-1800$; II: 1800 2000; III: 2000-2200. These temperature intervals for the classes being narrower than those defined in the Winkler criteria, allow for a better discrimination of the thermal variability within short distances as it occurs in the Azores islands where cloudiness and humidity degree can show significant differences in relatively short distances affecting local energy balance; the altitude is the factor which mostly defines its differentiation.

The three thermal intervals referred to climate maturity groupings were combined with a single slope interval of 0 $15 \%$ to exclude the landscape units above this limit. The resulting composite grid for each island was finally combined with the respective digitized soil map to select and incorporate the cartographic units of Hapludands, Udivitrands and Eutrudepts, whose average parameters of drainage, wa- ter holding capacity, depth to bedrock and $\mathrm{pH}$, fall within the adequacy limits for grapevine growth and production, as depicted from the soil survey database and reports.

\subsection{Climate}

The Azores Archipelago, located in the middle of the Atlantic Ocean basin, north of the predominant influence of the trade winds and on the influence of the subtropical highpressure belt, sits in an area of transition and confrontation between air masses from the tropics and colder air masses coming from the North. Sufficiently far apart from the continental coasts, the air masses that hit the Azores islands reveal a strong increment in properties associated with their maritime route. In this geographic context, the climate of the Azores islands depends, quite evidently, on their geographical setting and relationship with the surrounding sea. Normal climatology and sequential water balance for the lower altitudes $(<100 \mathrm{~m})$ of the Azores islands is presented in Fig. 2.

A strong climatic differentiation can be observed in altitude, as well as significant climatic asymmetries inland of each island. The spatial expression of the climatic elements is related in each island with its dimension and orography, the topographical orientation, the superficial geologic structure, the top soils and the vegetation. In some cases the climate of one island is affected by the shadow effect from its neighboring islands (Azevedo, 1996).

Locally, important subscale characteristics and mechanisms have a prominent role in the climatic spatial differentiation. Advective transport of air and the consequent adiabatic cooling due to the orographic obstacle is determinant in the configuration of the temperature and humidity fields. The same mechanism is in the origin of the orographic clouds generation that, besides the direct role as water source by the reinforcement of precipitation, have an indirect but important interference on the local water balance since they act like a filter to direct solar radiation and as a source of long-wave radiation affecting the local balance of energy. Also, the saturation (or near saturation) conditions that they provide constitute a barrier to water vapor diffusion in the mechanisms of evapotranspiration (Azevedo et al., 1998).

The annual average air temperature on the coast of Pico Island (the one that presents the greatest climatic diversity 
of the whole archipelago) is around $18.0^{\circ} \mathrm{C}$, with an average minimum of $10.5^{\circ} \mathrm{C}$ in February and maximum of over $26.0^{\circ} \mathrm{C}$ in August. The annual average diurnal amplitude is low, around $6.0^{\circ} \mathrm{C}$. As the altitude increases, the temperature decreases regularly approximately at a ratio of $0.9^{\circ} \mathrm{C}$ per $100 \mathrm{~m}$ (dry adiabatic lapse rate) until the dew point temperature is reached at an average altitude of about $600 \mathrm{~m}$. From that point on, until the top of the islands under the orographic cloud cover, the temperature decreases at a slower rate, at an average of $0.5^{\circ} \mathrm{C}$ per $100 \mathrm{~m}$, due to the effect of energy transfer to the atmosphere by the condensation process.

Particular aspects of the climate of the islands can also be explained locally by its singular geology as is the case of the unevolved lava fields in many cases traditionally occupied by vineyards. In these situations, the mild climate felt on the littoral of the islands is now a result of the conjugated effect of the ocean's proximity and the high thermal accumulation capacity of the black basalt lava flows, a situation that also inversely affects the relative humidity of the air (Azevedo, 2014).

The wind is a constant of the Azorean climate. Throughout the year the wind blows regularly, more moderately in the summer months, and more vigorously in the winter. The wind speed increases from islands of the Oriental Group to the ones on the Occidental Group. Generally, in winter, the syncopated evolution of the low pressure systems north of the Archipelago leads to the winds circumventing the islands by north and from the west to the east. During the summer, with the rise in latitude of the high pressure systems, the islands are besieged by winds from the southwest. The wind speed increases with altitude and as the atmospheric circulation releases itself gradually from the friction of the planetary boundary layer, all the while assuming greater regularity on its orientation. On the coast of the islands the annual average wind speed is around $17 \mathrm{~km} \mathrm{~h}^{-1}$. In the winter months the average velocity approaches $20 \mathrm{~km} \mathrm{~h}^{-1}$, although gusts reaching $100 \mathrm{~km} \mathrm{~h}^{-1}$ are felt almost every year. In the summer months, on the contrary, the wind velocity decreases to values under $10 \mathrm{~km} \mathrm{~h}^{-1}$. It is also in this period that, due to the diminishing influence of the higher predominance systems, we can observe the formation of coastal breezes on the larger Islands of the Azores (Azevedo, 2014).

According to the Köppen-Geiger climate classification (Essenwanger, 2001; Peel et al., 2007), the littoral climate of the Azores archipelago is included in the temperate climates category (group C), characterized by having a summer and a winter and an average temperature of the colder month below $18^{\circ} \mathrm{C}$ but above $-3^{\circ} \mathrm{C}$. However, the diagonal distribution of the islands across an extension of about $700 \mathrm{~km}$, leads to its climate being classified from east to west as a transition between the $C s$ and $C f$ subgroups, respectively, evolving from temperate rainy climate with dry summer (eastern islands) to temperate rainy climate, humid on all seasons (western islands). Still, according to the same classification system, the mildness of the island's climate can be emphasized by com- bining the letter $b$ with these two codes, becoming, both of them, $C s b$ and $C f b$, meaning that the average temperature of the warmest month is on average below $22^{\circ} \mathrm{C}$. The oceanic characteristics of the archipelago is stressed in the western islands of Flores and Corvo where the oceanic conditions are mostly accentuated.

In this work the CIELO model (Clima Insular à Escala LOcal) (Azevedo, 1996; Azevedo et al., 1998, 1999), has been used to set up spatial climatic differentiation based on climate and/or maturity classes. The CIELO is a physically based model that simulates numerically the transformations of the climatic variables in an island using data from a synoptic reference weather station or downscaling from a lower resolution climatic model. The model reproduces through finite difference methods the thermodynamic transformations experienced by an air mass crossing the island, and simulates the evolution of the air parcel's properties starting from the sea level that justify the values observed in the reference weather station. The domain of computation is based on the digital elevation models of the islands (DEM).

The model consists of two main sub-models. One, relative to the advective component simulation, assumes the Foehn effect to reproduce the dynamic and thermodynamic processes. This makes it possible to simulate the fields of the air temperature, air humidity, cloudiness and precipitation as influenced by the orography along its trajectory. The second concerns the radiative component as affected by the clouds of orographic origin and by the shadow produced by the relief.

The CIELO model has been successfully applied for modeling species distributions (e.g. Hortal et al., 2010; JiménezValverde et al., 2009; Aranda et al., 2011; Boieiro et al., 2013; Florencio et al., 2013; Guerreiro et al., 2014) and patterns of species richness (e.g. Borges et al., 2006) in the Macaronesian islands.

\subsection{Topography}

The topography influences grapevine growth and quality through elevation, slope, exposure and morphology of the proximate landscape which may also define the occurrence of microclimatic zones (Van Leeuwen and Seguin, 2006).

In this work the topography was analyzed based on the tridimensional models of the islands in GIS. Instead of various slope classes we considered only one global interval in the $0-15 \%$ range as the suitability limit to include the best slopes for the mechanization of the vineyard cultural operations (Jones et al., 2004).

\subsection{Soils}

Soils of the Azores archipelago originate from modern volcanic materials that have evolved under the humid and moderate Atlantic climate. In general they accomplish the criteria to be classified in the Andisol Order (Soil Survey Staff, 2014). 

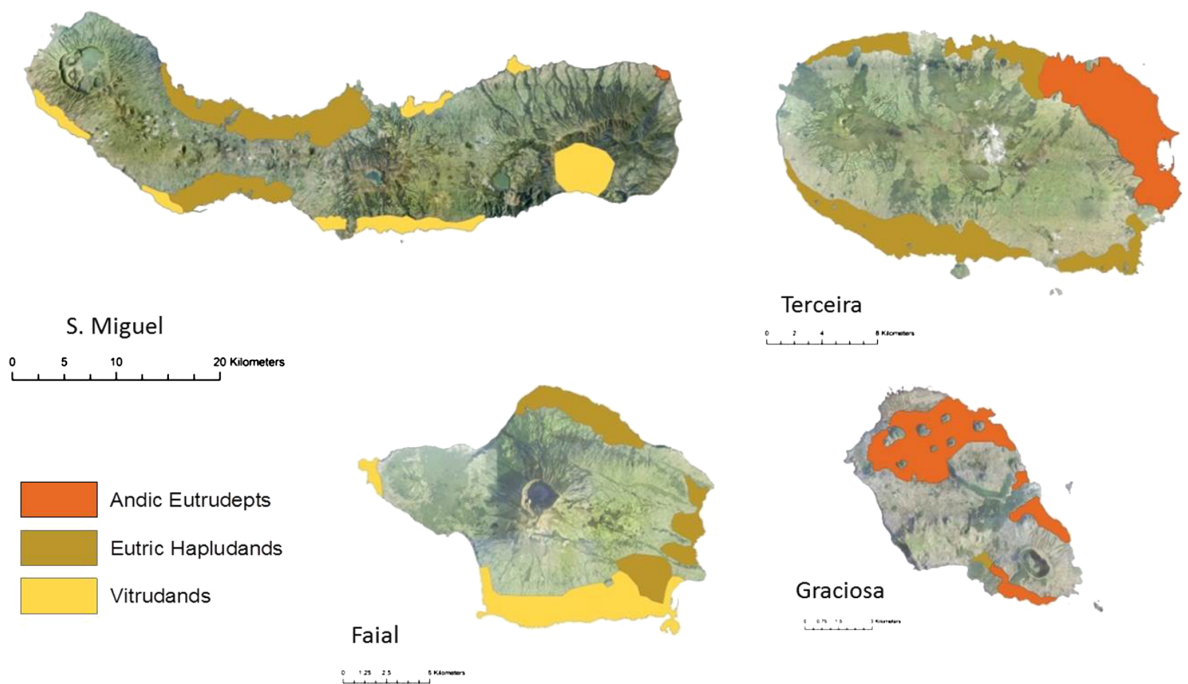

Terceira
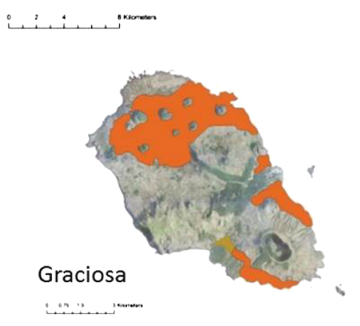

Figure 3. Major soil categories represented in potential new areas for viticulture in S. Miguel, Terceira, Faial and Graciosa islands of the Azores.

The typical parent material of Andisols is tephra, a general term for all airborne volcanic ejecta, regardless of morphology, size and composition, being often quite porous with a large active specific surface. It is also difficult to determine the mineralogy of tephra because of microcrystallinity and/or non-crystalline nature of the materials (Dahlgren et al., 1993).

Andisols present unique soil properties resulting from the weathering of volcanic materials and in particular of their tephra glassy products which show a very low resistance to chemical weathering, suffering a rapid evolution to the formation of large amounts of non-crystalline products, usually referred in literature as short range-order materials (SROM). The noncrystalline materials consist primarily of allophane, imogolite and ferryhidrite (Parfitt and Kimble, 1989). In the Azores, at the lower altitudes where climatic conditions can be marked by a dry spell in the summer, the Andisols show an evolutionary tendency to other soil categories mainly of the Inceptisol Order, especially in the more stable and older geological areas of the islands (Pinheiro, 1990). Andisols may have $\mathrm{AC}, \mathrm{ABC}$, or multisequa of these horizon sequences, as the soil environment is characterized by deposition of parent materials, gradually or repeatedly being buried under new fresh vitric materials. Vitrands formed from thick pumice or scoria tephras show the AC profile while intermittent tephra deposition and subsequent soil formation result in the development of other Andisols with a multisequum profile (Shoji et al., 1993).

Soils of the Azores Archipelago have been studied in detail, and their characteristics and classification have been discussed in several papers (Auxtero et al., 2004; Pinheiro et al., 2001, 2004; Madeira, 1980; Madeira et al., 2002, 2003; Pinheiro, 1990, 1999; Madruga, 1995; Medina and Grilo, 1981; Ricardo et al., 1977).
For the present study soils were analyzed based on data and soil map units as defined in the soil surveys of the Azores archipelago (ongoing project by the soils group of the University of the Azores). As presented in the maps in Fig. 3, Hapludands and Udivitrands great groups of the Andisol as well as Eutrudepts (Inceptisols) (Soil Survey Staff, 2014) where the andic character is only weakly expressed, were selected as the taxonomic soil categories mostly represented in the lower surfaces of the islands and where grapevine growth can be admitted. Table 1 shows some analytical data of representative pedons of the major cartographed soil units, mostly selected as significant soil properties for viticulture.

The soil conditions of the delineated new areas are hardly comparable to the traditional vineyards of the Azores since these ones have been settled over cracked lava fields where even the hydric and nutrient plant nourishment processes are frequently difficult to access and to explain. Additionally to the stony condition of the terrain, the micro parcel structure of the vineyards drastically limits the workability and trafficability of the traditional vineyards, making them highly costly and dependent on man labor for almost every management practices. Figure 4 shows the distribution of the existing traditional vineyard areas and DOC (Denominação de Origem Conhecida) limits.

The soil properties taken as the most relevant for the analysis and definition of the potential vineyard areas were drainage, water holding capacity, depth to bed-rock and $\mathrm{pH}$. From these parameters, soil suitability classes were defined (Table 2) based on the concept and criteria as adapted from Bucelli and Costantini (2009). Table 3 show the areas of the soil suitability classes for each island, based on the soil parameters as established in Table 2.

Soil drainage, being dependent on various soil characteristics such as texture, structure depth and slope, affects crop 
Table 1. Pedological properties of three soils representative of the potential new areas for viticulture in the Azores.

\begin{tabular}{|c|c|c|c|c|c|c|c|c|c|c|c|c|c|c|}
\hline \multirow{3}{*}{$\begin{array}{l}\text { Soil } \\
\text { horizons }\end{array}$} & \multirow{3}{*}{$\begin{array}{l}\text { Depth }^{\mathrm{a}} \\
(\mathrm{cm})\end{array}$} & \multirow{3}{*}{$\begin{array}{l}\text { Bulk } \\
\text { density } \\
\left(\mathrm{g} \mathrm{cm}^{-3}\right)\end{array}$} & \multicolumn{2}{|c|}{ Water retention } & \multirow{3}{*}{$\begin{array}{l}\mathrm{pH} \\
\left(\mathrm{H}_{2} \mathrm{O}\right)\end{array}$} & \multirow{3}{*}{$\begin{array}{l}\text { Organic } \\
\text { carbon } \\
\left(\mathrm{g} \mathrm{kg}^{-1}\right)\end{array}$} & \multicolumn{5}{|c|}{ Exchangeable bases ${ }^{\mathrm{b}}$} & \multirow{3}{*}{$\begin{array}{l}\text { Allophane } \\
(\%)\end{array}$} & \multirow{3}{*}{$\begin{array}{l}\text { Textural } \\
\text { class }^{d}\end{array}$} & \multirow{3}{*}{$\begin{array}{l}\text { Coarse fraction } \\
>2 \mathrm{~mm} \\
(\text { vol. } \%)\end{array}$} \\
\hline & & & $300 \mathrm{kPa}$ & $1500 \mathrm{kPa}$ & & & $\mathrm{Ca}^{2+}$ & $\mathrm{Mg}^{2+}$ & $\mathrm{K}^{+}$ & $\mathrm{Na}^{+}$ & $\sum$ & & & \\
\hline & & & \multicolumn{2}{|l|}{$\mathrm{cm}^{3} \mathrm{~cm}^{-3}$} & & & \multicolumn{5}{|c|}{$\left(\operatorname{cmol}(+) \mathrm{kg}^{-1}\right)$} & & & \\
\hline \multicolumn{15}{|c|}{ Andic Eutrudepts (pedon Vila-Nova) } \\
\hline Ap & $0-27$ & 1.1 & 0.27 & 0.15 & 5.8 & 24 & 2.7 & 0.8 & 0.9 & 0.7 & 5.1 & nd & $\mathrm{L}$ & 6.8 \\
\hline Bw1 & $27-60$ & 1.0 & 0.35 & 0.17 & 6.0 & 19 & 3.6 & 0.7 & 0.6 & 0.5 & 5.4 & nd & SCL & 4.3 \\
\hline Bw2 & $60-76$ & 0.9 & 0.54 & 0.29 & 5.9 & 15 & 5.0 & 1.1 & 0.4 & 1.0 & 7.5 & 3 & SCL & 3.1 \\
\hline $2 \mathrm{Bwb}$ & $76-120$ & 0.9 & 0.50 & 0.36 & 5.9 & 7 & 5.0 & 1.2 & 1.0 & 1.6 & 8.8 & 5 & CL & 0 \\
\hline $3 \mathrm{Bwb}$ & $120-160+$ & 0.8 & 0.58 & 0.33 & 6.4 & 7 & 7.9 & 1.7 & 0.1 & 0.7 & 10.4 & 6 & $\mathrm{CL}$ & 0 \\
\hline \multicolumn{15}{|c|}{ Eutric Hapludands (pedon Altares) } \\
\hline Ap & $0-38$ & 0.8 & 0.46 & 0.19 & 5.6 & 5.8 & 6.5 & 3.3 & 0.2 & 1.2 & 11.2 & 7 & SL & 7.6 \\
\hline Bw1 & $38-87$ & 0.7 & 0.44 & 0.25 & 5.7 & 4.2 & 2.5 & 1.0 & 0.2 & 0.6 & 4.3 & 15 & SCL & 3.2 \\
\hline $\mathrm{Bw} 2$ & $87-155$ & 0.7 & 0.79 & 0.32 & 6.6 & 3.1 & 10.7 & 4.0 & 0.1 & 3.1 & 17.9 & 24 & CL & 1.7 \\
\hline $2 \mathrm{Bwb}$ & $155-200+$ & 0.8 & 0.35 & 0.21 & 7.3 & 0.4 & 9.0 & 3.7 & 0.2 & 1.9 & 14.8 & 10 & SCL & 10.4 \\
\hline \multicolumn{15}{|c|}{ Typic Udivitrands (pedon FA 11) } \\
\hline Ap & $0-40$ & 0.8 & 0.34 & 0.18 & 5.4 & 4.6 & 3.7 & 1.5 & 0.3 & 1.2 & 6.7 & 5 & SL & $18.5^{\mathrm{f}}$ \\
\hline BC1 & $40-70$ & 0.9 & 0.31 & 0.13 & 5.6 & 2.9 & 1.2 & 0.7 & 0.4 & 0.8 & 3.1 & 7 & LS & $45.6^{\mathrm{f}}$ \\
\hline $\mathrm{BC} 2$ & $70-90$ & $\mathrm{ed}^{\mathrm{a}}$ & 0.24 & 0.09 & 6.0 & 0.3 & 1.1 & 0.3 & 0.1 & 0.8 & 2.3 & 2 & LS & $48.5^{f}$ \\
\hline $\mathrm{C}$ & $90-160+$ & nd & 0.15 & 0.09 & 6.3 & 0.2 & 0.5 & 0.2 & 0.1 & 0.8 & 1.6 & 1 & nd & $76.8^{f}$ \\
\hline
\end{tabular}

a depth to bedrock indetermined within the limits of the pedon.

b determined by the ammonium acetate method at $\mathrm{pH} 7$.

c estimated according to Parfitt (1986) and based on Si and Al ratio extracted by acid ammonium oxalate (Blakmore et al., 1987).

${ }^{\mathrm{d}}$ LS - loamy sand; SL - sandy loam; L - loam; SCL - sandy clay loam; CL - clay loam

e not determined.

${ }^{f}$ pomice
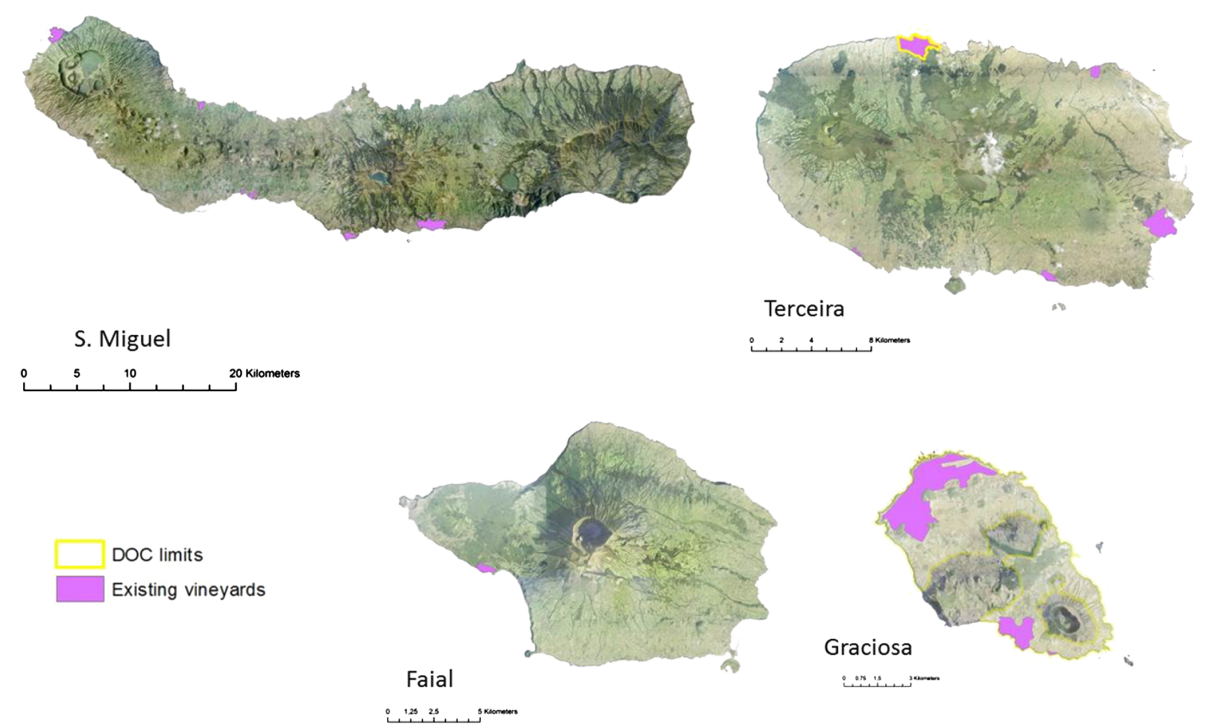

Figure 4. Distribution of the existing traditional vineyard areas and DOC limits in the Azores Islands.

health and management conditions. Soil depth, not only defines the soil volume for root development and mineral nutrition as it defines and limits the available soil water capacity. Soil $\mathrm{pH}$, being a regulator of chemical and biological processes, gives an indication of the potential for nutrient availability. The neutral to slightly acid reaction is the best $\mathrm{pH}$ condition for nutrient fertility and balance in the soil. However, it is well recognized that the nutritive fertility for grapevines should be only moderate, as a high nutritional condition leads to excessive vegetative growth and induces an overall lowering of the quality parameters in the wine.

Different water levels in the soil affect grape quality and reflects in wine quality (Conradie et al., 2002). Andisols can retain a large amount of water primarily due to their large volume of mesopores and micropores produced within the stable soil aggregates.

Formation of these aggregates is greatly enhanced by noncrystalline materials and soil organic matter (Maeda et al., 1977). 
Table 2. Functional soil parameters and suitability classes of the potential new areas for viticulture in the Azores.

\begin{tabular}{llll}
\hline Soil parameters & \multicolumn{3}{c}{ Suitability class } \\
\cline { 2 - 4 } & $\mathrm{S} 1$ & $\mathrm{~S} 2$ & $\mathrm{~S} 3$ \\
\hline Drainage class* & Well drained & $\begin{array}{l}\text { somewhat excessively drained, } \\
\text { or moderately well drained }\end{array}$ & $\begin{array}{l}\text { excessively drained, or } \\
\text { somewhat poorly drained }\end{array}$ \\
AWC $\left(\mathrm{cm}^{3} \mathrm{~cm}^{-3}\right)$ & $>0.20$ & $0.15-0.20$ & $0.15-0.10$ \\
Rooting depth $(\mathrm{cm})$ & $>100$ & $50-100$ & $25-50$ \\
pH $\left(\mathrm{H}_{2} \mathrm{O}\right)$ & $6.5-7.5$ & $5.5-6.5$ & $4.8-5.5$ \\
\hline
\end{tabular}

* Soil Survey Manual

Table 3. Areas (ha) of the suitability classes for viticulture in the Azores islands.

\begin{tabular}{lrrr}
\hline Island & \multicolumn{3}{c}{ Suitability class (ha) } \\
\cline { 2 - 4 } & S1 & S2 & S3 \\
\hline S. Miguel & 4052 & 4421 & 1794 \\
Terceira & 9116 & 0 & 0 \\
Faial & 1401 & 1502 & 0 \\
Graciosa & 1483 & 0 & 0 \\
\hline
\end{tabular}

High water permeability is a distinctive physical property of volcanic ash soils under both saturated and unsaturated conditions. Under unsaturated conditions, Andisols have greater hydraulic conductivity than other mineral soils such as clayed alluvial soils (Nanzio et al., 1993). Both Hapludands and Udivitrands of the considered areas generally present average to good drainage conditions without impeding layers. Even the finer textured Hapludands, found in the older geological areas of the islands Terceira (Pinheiro, 1999) and Graciosa (Medina and Grilo, 1981) showing an eutric character, have no drainage constraints.

In these soils the available water-holding capacity (AWC) is relatively high, varying between 0.20 and $0.25 \mathrm{~cm}^{3}$ of water per $1 \mathrm{~cm}^{3}$ of soil. The Udivitrands, which predominate in the islands of S. Miguel (Ricardo et al., 1977) and Faial (Madeira et al., 2002), have in general coarse textures with significant fractions of pomice and cinders fragments from sand to gravel dimensions. Under these textural conditions the water holding capacity may be somewhat limited. As in these soils the internal drainage is frequently very high, these combined factors may increase the risk of drought periods during the growing season and the average interval of AWC variation lowers to $0.10-0.15 \mathrm{~cm}^{3}$ of water per cubic centimeter of soil in the Udivitrands. Nevertheless, it has been observed that a certain lack of water during the ripening period is favorable to the organoleptic wine quality (Galet, 1993; Riou et al., 1994; Huglin and Schneider, 1998).

In volcanic landscapes the profile characteristics concerning horizon sequence and thickness can be quite variable even within short distances. Depth to bed rock of the Haplu- dands in the selected areas averages $60 \mathrm{~cm}$ with no less than $40 \mathrm{~cm}$ and the Udivitrands are in general more than $1 \mathrm{~m}$ deep.

The soil reaction found in the considered altitudes for both soil categories is in general slightly acid to neutral, being the $\mathrm{pH}$ range of 5.6 to 6.5 . From a soil standpoint, high-quality wines are made from grapes grown in many different types of soils with no single type considered ideal (Wilson, 1998). Grapevines will tolerate a wide range of soils, but yield and variation in vine vigor commonly match changes in local soil properties, which in turn can influence grape characteristics (Bramley, 2001, 2005; Reynolds et al., 2007). In spite of the relative variability in both physical and chemical parameters as generally described above, the soils considered here reflect an overall suitability for the viticulture expansion in the Azores.

\section{Results and conclusions}

Along the last half-century the agricultural activity in the Azores has been progressively concentrated to the milk industry. Presently, the wine production represents a very small part of the economy, around $0.3 \%$ of the agricultural product as referred to in the new program of rural development of the Azores - Prorural 2014-2020. However, the ongoing abolishment of milk quotas in the EU and the increased risk on milk price volatility is expected to negatively affect the economical behavior of the dairy industry in the Azores.

This research provides a definition of the environmental characteristics of potential new areas of higher yielding vineyards under technically adequate mechanization conditions, allowing an efficient management of the crop and improvement of the wine industry in the Azores, contributing thus to the diversification and development of the agricultural sector as a whole.

Here, we attempt to define and map landscape areas with apparent potential for grapevine growing in the Azores islands of S. Miguel, Terceira, Faial and Graciosa, as an alternative to the traditional terroir. The lava field terroir was not included in the potential areas here defined because the management costs imposed by the peculiarities of these vineyards, established over a micro parcel and stony structure, 

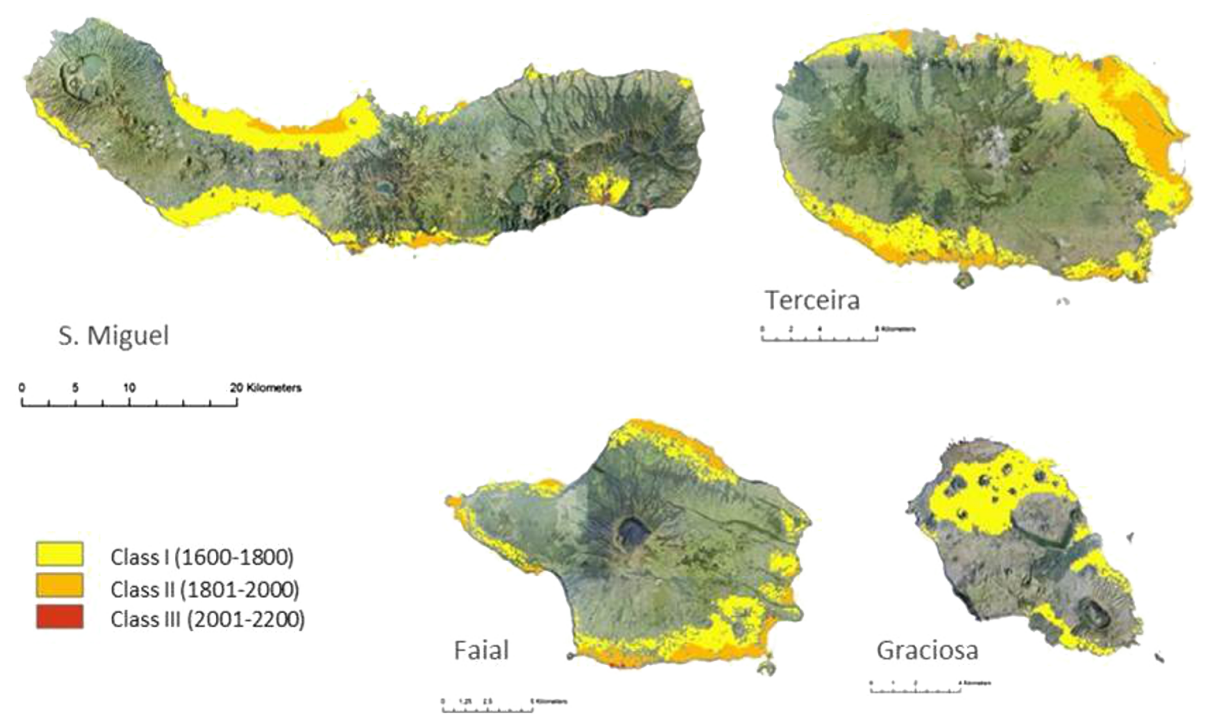

Class II (1801-2000)

Class III (2001-2200)

Figure 5. Composite landscape units with potential for viticulture in each island with distribution depicted by climate maturity groups.

deny their economical sustainability and maintenance in the Azores, except under significant government funding as it is the case of the UNESCO protected vineyard area in Pico island.

Under the specificity of the Azorean environmental conditions, white wines produced from several adapted winegrape varieties (e.g.,Verdelho, Arinto and Terrantês), which started to be introduced in the Archipelago since the 15th century in the advent of the colonization of the islands and probably originated from Cyprus and the Madeira islands (Duarte Jr., 2001), have been more successful than red wines most probably due to the generally lower heat demand for maturation of the white grape varieties. The more recognized and typical white wines of the Azores have been produced in the lava field terroirs of Pico, both table and dessert wines. Biscoitos, a small village of stony volcanic cover in Terceira island, is also recognized by its white wines in spite of the reduced overall production. There are very few studies of chemical characterization of wines from the Azores. Ribeiro de Lima et al. (2004) found that the concentrations of iron, copper manganese and zinc in Azorean wines correspond with the mean values observed for other regions in Europe. Batista et al. (2001) presented a comparison study of polyphenols and aroma in red wines from the Portuguese mainland versus the Azores islands.

The spatial potential for viticulture of each island is presented in the maps in Fig. 5, with the area distribution depicted by climate maturity groups. The cartographic representation of these landscape areas resulted from a GIS supported spatial analysis of climate, soils and topography based on the combination of the selected criteria for each of these three factors. Three thermal classes defined as climate/maturity groupings were established from a baseline reference (vineyards area of Pico island), and then combined
Table 4. Areas (ha) with potential for grapevine production for each island and climate maturity class.

\begin{tabular}{lrrr}
\hline \multirow{2}{*}{ Island } & \multicolumn{3}{c}{ Climate } \\
\cline { 2 - 4 } & I & II & III \\
\hline S. Miguel & 8696 & 1541 & 30 \\
Terceira & 6088 & 3028 & 0 \\
Faial & 1848 & 1042 & 13 \\
Graciosa & 1483 & 0 & 0 \\
\hline Total & 18115 & 5611 & 43 \\
\hline
\end{tabular}

with the soils fulfilling the most advantageous characteristics of moderate to good drainage, adequate soil depth, fair to good water-holding capacity and near neutral $\mathrm{pH}$, and being distributed within a slope interval of 0 to $15 \%$ taken as the most adequate to the vineyard cultural operations.

The calculated surfaces (ha) of the cartographic areas with potential for grapevine production, as defined for each island and thermal class are presented in Table 4. The warmer conditions of thermal class III, well represented in the traditional terroir of Pico island, has practically no expression in the other islands. However, for the intermediate class II and the cooler class I, we could map significant areas - 5611 and 18115 ha respectively - fulfilling the defined soils and slope criteria. These results indicate that landscape units exist across the climate maturity classes II and I of the studied islands revealing adequate potential for future development of viticulture, although certainly demanding a good judgment on the better grape varieties to be adapted to those climatic conditions.

The defined thermal classes, based in the degree-day concept for a base temperature of $10^{\circ} \mathrm{C}$ (Amerine and Winkler, 


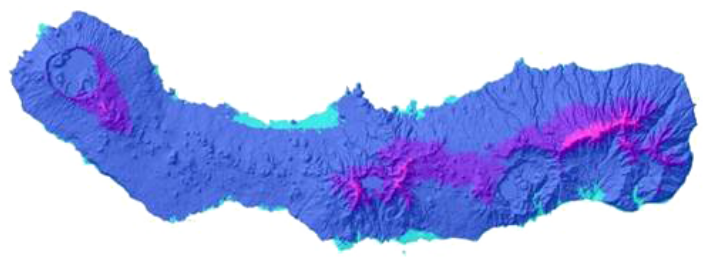

S. Miguel
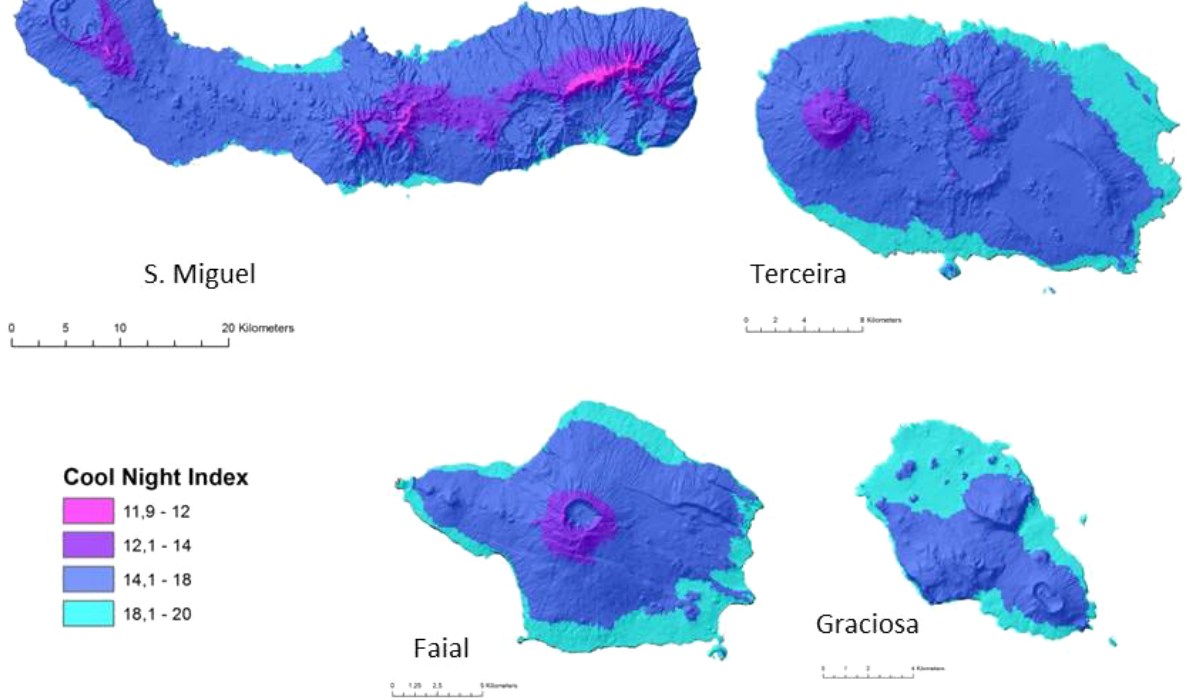

Figure 6. Cool Night Index (September average minimum temperature).

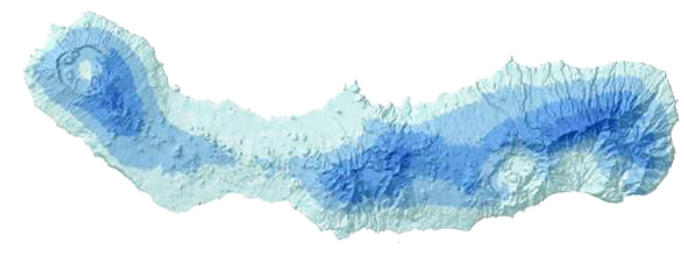

S. Miguel
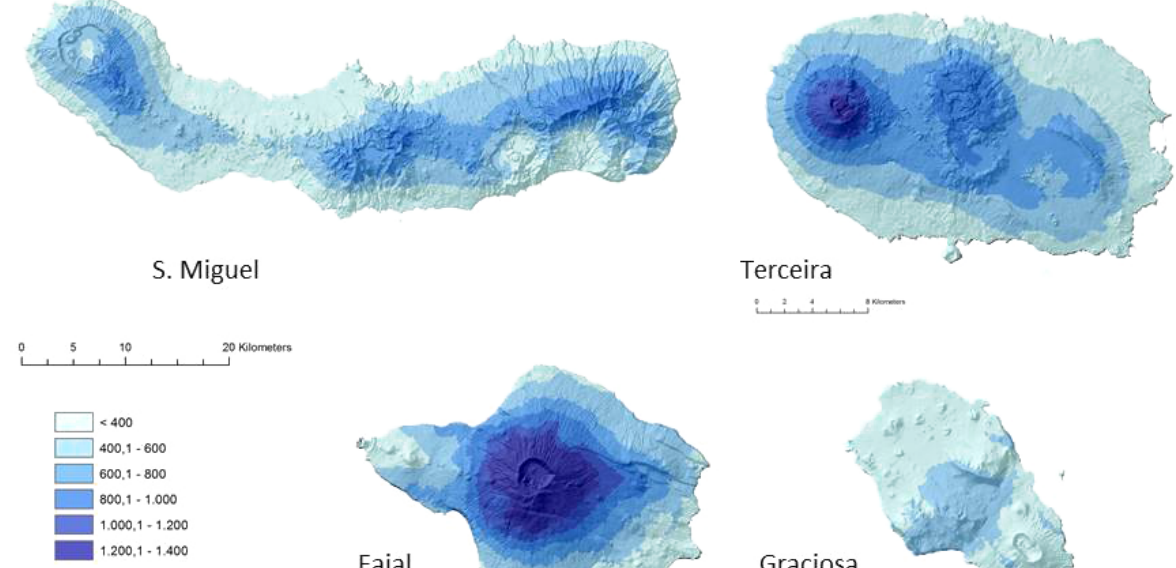

Growing season

accumulated precipitation
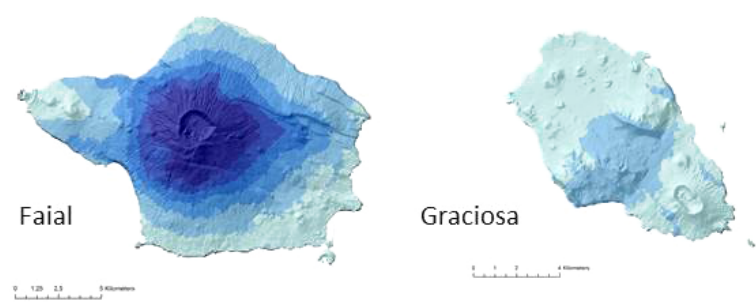

Figure 7. Growing season accumulated precipitation in millimeters (April-October).

1944), that we used as climatic indicators for viticultural zoning in the Azores, may be broadly compared to the bioclimatic index (CatI) which incorporates the most relevant characteristics of a given region, as defined for the Portugal mainland (Fraga et al., 2013). The Azores climate has been characterized as humid and the average daily temperatures in the lower areas are moderate with low thermal amplitudes and warm nights (above $14^{\circ} \mathrm{C}$ ) along the growing season, due to the maritime regulatory influence. The littoral of the islands covered by the three considered classes falls in the categories of temperate nights (September average $T_{\min }>14$ $18^{\circ} \mathrm{C}<$ ) and warm nights (September average $T_{\min }>18^{\circ} \mathrm{C}$ ) as it is defined by the Cool Night Index (CI) (Tonietto and
Carbonneau, 2004), Fig. 6. The Growing season accumulated precipitation varies from 400 to $800 \mathrm{~mm}$, Fig. 7. Consequently, the thermal classes I and II defined in this study can be broadly compared to the category 8 of the CatI bioclimatic index which is described as temperate, humid with warm nights, while the thermal class III would be better comparable to the category 12 which represent the warmer conditions found in the lava field grapevines of Pico island, where average temperatures are amplified by the heat capacity of the basaltic stones where the grapevines are laying.

The present study, through the use of overlay GIS spatial analysis based on climate, soils and slope, conducted at an intermediate scale level, provides an overall perspective and 
understanding of the potential for expansion of viticulture in the Azores. Additionally, the results presented should serve as a decision support tool in the site selection process for new vineyards establishment. However, there are limitations and further issues to be addressed before developing any individual site. In fact, the resolution limits of the landscape analysis, related to elevation and slope data as well as to soils variability, request a detailed site specific assessment to be conducted prior to any final decision on a new vineyard establishment. The expansion of the viticulture onto new soil types will also affect resulting grape and wine characteristics and will imply an additional effort of experimental study and research on the adaptation of traditional and new varietals to the alternative environmental conditions here defined. Furthermore, future research activities on viticultural and oenological results are needed to check the wine suitability of the delineated new areas of potential natural terroir units.

Author contributions. E. B. Azevedo developed the climatic analysis and with F. Reis and F. Fernandes they adapted the GIS model. J. Madruga and J. Sampaio selected the background soils data and analysis. J. Pinheiro participated in soil analysis and prepared the manuscript with contributions from all co-authors.

Acknowledgements. The climatic CIELO model simulations for this work were done under the framework of the project ESTRAMAR (FEDER - MAC/3/C177) from the Program MAC 2007-2013, Transnational Cooperation. The CITA_A and the CCMMG are partially supported by the Autonomous Government of the Azores, through the Regional Fund for Science.

Edited by: E. Costantini

\section{References}

Amerine, M. A. and Winkler, A. J.: Composition and quality of must and wines of California grapes, Hilgardia, 15, 493-675, 1944.

Aranda, S. C., Gabriel, R., Borges, P., Azevedo, E. B., and Lobo, J. M.: Designing a survey protocol to overcome the Wallacean shortfall: a working guide using bryophyte distribution data on Terceira Island (Azores), Bryologist, 114, 611-624, 2011.

Auxtero, E., Madeira, M., and Sousa, E.: Variable charge characteristics of selected Andisols from the Azores, Portugal, Catena, 56, 111-125, 2004.

Azevedo, E. B.: Modelação do Clima Insular à Escala Local. Modelo CIELO aplicado à ilha Terceira, Ph.D. thesis, University of the Azores, Portugal, 247 pp., 1996.

Azevedo, E. B.: Climate Overview, in: Pico Island Natural History Handbook, Observatório Vulcanológico e Geotérmico dos Açores, 2014.

Azevedo, E. B., Pereira, L. S., and Itier, B.: Modeling the Local Climate in Islands Environments, Orographic Clouds Cover, in: First International Conference on Fog and Fog Collection, IDRC, Ottawa, Canada, 433-436, 1998.
Azevedo, E. B., Pereira, L. S., and Itier, B.: Modelling the local climate in island environments: water balance applications, Agr. Water Manage., 40, 393-403, 1999.

Baptista, J. A. B., Tavares, J. F., and Carvalho, R. C. B.: Comparison of polyphenols and aroma in red wines from Portuguese mainland versus Azores Islands, Food Res. Int., 34, 345-355, 2001.

Blakemore, L. C., Searle, P. L., and Daly, B. K.: Soil bureau laboratory methods: a method for chemical analysis of soils, New Zealand: Soil Bureau Scientific Report 80, 1987.

Boieiro, M., Carvalho, J. C., Cardoso, P., Aguiar, C. S., Rego C., Silva, I. F., Amorim, I. R., Pereira, F., Azevedo, E. B., Borges, P. B., and Serrano, A. M.: Spatial Factors Play a Major Role as Determinants of Endemic Ground Beetle Beta Diversity of Madeira Island Laurisilva, PLoS ONE, 8, e64591, doi:10.1371/journal.pone.0064591, 2013.

Borges, P. A. V., Lobo, J. M., Azevedo, E. B., Gaspar, C., Melo, C., and Nunes, L. V.: Invasibility and species richness of island endemic arthropods: a general model of endemic vs. exotic species, J. Biogeogr., 33, 169-187, 2006.

Bramley, R. G. V.: Progress in the development of precision viticulture variation in yield, quality and soil properties in contrasting Australian vineyards, in: Precision Tools for Improving Land Management: Occasional Report No. 14, edited by: Currie, L. D. and Loganathan, P., Fertilizer and Lime Research Centre, Massey University: Palmerston North, New Zealand, 25-43, 2001.

Bramley, R. G. V.: Understanding variability in wine grape production systems 2 . Within vineyard variation in quality over several vintages, Aust. J. Grape Wine Res., 11, 33-42, 2005.

Bucelli, P. and Costantini, E. A. C.: Wine Grape and Vine zoning, in: Manual of methods for soil and land evaluation, edited by: Costantini, E. A. C., Science Publishers, Enfield (NH), USA, 353-400, 2009.

Conradie, W. J., Carey, V. A., Bonnardot, V., Saayman, D., and Schoor van, L. H.: Effect of different environmental factors on the performance of Sauvignon blanc grapevines in the Stellenbosch/Durbanville districts of South Africa. I. geology, soil, climate, phenology and grape composition, S. Afr. J. Enol. Vitic., 23, 79-91, 2002.

Dahlgren, R., Shoji, S., and Nanzyo, M.: Mineralogical characteristics of volcanic ash soils, in: Volcanic Ash Soils. Genesis, Properties and Utilization, edited by: Shoji, S., Nanzyo, M., and Dahlgren, R. A., Developments in Soil Science 21, Amsterdam, Elsevier, 101-143, 1993.

Deloire, A., Vaudour, E., Carey, V., Bonnardot, V., and van Leeuwen, C.: Grapevine responses to terroir: A global approach, J. Int. Sci. Vigne Vin, 39, 149-162, 2005.

Duarte Jr., T.: O Vinho do Pico, Coingra Lda, 301 pp., 2001.

Dutt, G., Mielke, E. A., and Wolfe, W. H.: The use of soils for the delineation of viticultural zones in the four corners region, Am. J. Enol. Viticult., 32, 290-296, 1985.

Essenwanger, O. M.: Classification of climates, World Survey of Climatology, General Climatology, Elsevier, Amsterdam, 102 pp., 2001.

Florencio, M., Cardoso, P., Lobo, J. M., Azevedo, E. B., and Borges, P. A. V.: Arthropod assemblage homogenization in oceanic islands: the role of indigenous and exotic species under landscape disturbance, Divers. Distrib., 19, 1450-1460, 2013.

Fraga, H., Malheiro, A. C., Moutinho-Pereira, J., Jones, G. V., Alves, F., Pinto, J. G., and Santos, J. A.: Very high resolution 
bioclimatic zoning of Portuguese wine regions: present and future scenarios, Reg. Environ. Change, 14, 295-306, 2013.

Galet, P.: Précis de viticulture, Montpellier, Déhan, 582 pp., 1993.

Guerreiro, O., Cardoso, P., Ferreira, J. M., Ferreira, M. T., and Borges, P. A. V.: Potential Distribu tion and Cost Estimation of the Damage Caused by Cryptotermes brevis (Isoptera: Kalotermitidae) in the Azores, J. Econ. Entomol., 107, 1554-1562, 2014.

Hortal, J., Borges, P. A. V., Jiménez-Valverde, A., Azevedo, E. B., and Silva, L.: Assessing the areas under risk of invasion within islands through potential distribution modelling: the case of Pittosporum undulatum in São Miguel, Azores, J. Nat. Conserv., 18, 247-257, 2010.

Huglin, P. and Schneider, C.: Biologie et Écologie de la Vigne, 370 pp., Lavoisier Tec \& Doc, Paris, 1998.

Jiménez-Valverde, A., Diniz, F., Azevedo, E. B., and Borges, P. A. V.: Species distribution models do not account for abundance: the case of arthropods in Terceira Island, Ann. Zool. Fenn., 46, 451-464, 2009.

Jones, G. J., Snead, N., and Nelson, P.: Geology and Wine 8. Modeling viticultural landscapes: A GIS analysis of the terroir potential in the Umpqua valley of Oregon, Geoscience Canada, 31, 167178, 2004.

Jones, G. V.: Climate and terroir: Impacts of climate variability and change on wine, in: Fine Wine and Terroir - The Geoscience Perspective, edited by: Macqueen, R. W. and Meinert, L. D., Geoscience Canada Reprint Series 9, Geological Association of Canada, 203-216, 2006.

Laville, P.: Unite's de terroir naturel et terroir. Une distinction nécessaire pour redonner plus de cohérence au système d'appellation d'origine, Bull. O.I.V., 745-746, 227-251, 1993.

Madeira, M.: Esboço Pedológico da Ilha da Santa Maria (Açores), Instituto Nacional de Investigação Científica, Lisboa, 68 pp., 1980.

Madeira, M., Pinheiro, J., Monteiro, F., Fonseca, M., and Medina, J.: Características físicas, químicas e mineralógicas dos solos da Ilha do Faial (Arquipélago dos Açores), Revista de Ciências Agrárias, 25, 53-66, 2002.

Madeira, M., Auxtero, E., and Sousa, E.: Cation and anion exchange properties of Andisols from the Azores, Portugal, as determined by the compulsive exchange and the ammonium acetate method, Geoderma, 117, 225-241, 2003.

Madruga, J., Azevedo E. B., J. Sampaio, J., Fernandes G., Pinheiro J., and Madeira, M.: Caracterização de Novas áreas Edafoclimáticas com Potencial para a Cultura da Vinha nos Açores, Congresso "A Vinha nas Regiões Mediterrâneas", Madalena (Pico), 2011.

Mackenzie, D. E. and Christy, A. G.: the Role of soil chemistry in wine grape quality and sustainable soil management in vineyards, Water Sci. Technol., 51, 27-37, 2005.

Madruga, J. S.: Características e Génese do Horizonte Plácico em Solos Vulcânicos do Arquipélago dos Açores, Tese de Doutoramento, Universidade dos Açores, Angra do Heroísmo, 1995.

Maeda, T., Takenaka, H., and Warkentin, B. P.: Physical properties of allophane soils, Adv. Agron., 29, 229-264, 1977.

Medina, J. M. B. and Grilo, J. T.: Esboço Pedológico da Ilha Graciosa (Açores), Instituto Nacional de Investigação Científica \& Universidade dos Açores, Lisboa, 1981.
Nanzio, M., Shoji, S., and Dahlgren, R.: Physical characteristics of volcanic ash soils, in: Volcanic Ash Soils, Genesis, Properties and Utilization, edited by: Shoji, S., Nanzyo, M., and Dahlgren, R. A., Developments in Soil Science 21, Amsterdam, Elsevier, 189-207, 1993.

Parfitt, R. L.: Towards understanding soil mineralogy: Part III. Notes on allophanes, New Zealand, Soil Bureau Laboratory Report 10A, 1986.

Parfitt, R. L. and Kimble, J.: Conditions for formation of allophane in soils, Soil Sci. Am. J., 53, 971-977, 1989.

Peel, M. C., Finlayson, B. L., and McMahon, T. A.: Updated world map of the Köppen-Geiger climate classification, Hydrol. Earth Syst. Sci., 11, 1633-1644, doi:10.5194/hess-11-16332007, 2007.

Pinheiro, J.: Estudo dos principais tipos de solos da ilha Terceira (Açores), Ph.D. thesis, University of the Azores, Portugal, 212 pp., 1990.

Pinheiro, J.: Caracterização geral dos solos da Ilha Terceira que se enquadram na Ordem Andisols, Anais do Instituto Superior de Agronomia, 47, 99-117, 1999.

Pinheiro, J., Madeira, M., Monteiro, F., and Medina, J.: Características e classificação dos Andossolos da Ilha do Pico (Arquipélago dos Açores), Revista de Ciências Agrárias, 24, 48-60, 2001.

Pinheiro, J., Rodriguez, A., and Salguero, M. T.: Genesis of placic horizon in Andisols from Terceira Island (Azores-Portugal), Catena, 56, 85-94, 2004.

Priori, S., Barbetti, R., L'Abate, G., Bucelli, P., Storchi, P., and Costantini, E. A. C.: Natural terroir units, Siena province, Tuscany, Journal Maps, 10, 466-477, 2014.

Reynolds, A. G., Senchuk, I. V., van der Reest, C., and de Savigny, C.: Use of GPS and GIS for elucidation of the basis for terroir: Spatial variation in an Ontario Riesling vineyard, Am. J. Enol. Viticult., 58, 145-162, 2007.

Ribeiro de Lima, M. T., Kelly, M., Cabanis, M., Cassanas, G., Matos, L., Pinheiro, J., and Blaise, A.: Determination of iron, copper, manganese, and zinc in the soils, grapes and wines of the Azores, J. Int. Sci. Vigne Vin, 38, 109-118, 2004.

Ricardo, R. P., Madeira, M., Medina, J. M. B., Marques, M. M., and Furtado, A. F. S.: Esboço pedológico da ilha de S. Miguel (Açores), Anais do Instituto Superior de Agronomia, 37, 275385, 1977.

Riou, Ch., Becker, N., Sotes Ruiz, V., Gomez-Miguel, V., Carbonneau, A., Panagiotou, M., Calo, A., Costacurta, A., Castro de, R., Pinto, A., Lopes, C., Carneiro, L., and Climaco, P.: Le déterminisme climatique de la maturation du raisin: application au zonage de la teneur em sucre dans la communauté européenne, Office des Publications Officielles des Communautés Européennes, Luxembourg, 322 pp., 1994.

Shoji, S., Dahlgren, R., and Nanzyo, M.: Genesis of Volcanic Ash Soils, in: Volcanic Ash Soils - Genesis, Properties and Utilization, Elsevier, Amsterdam - New York - Tokyo, 37-72, 1993.

Soil Survey Staff: Keys to Soil Taxonomy, 12th Edn., USDANatural Resources Conservation Service, Washington, DC, 2014.

Tonietto, J. and Carbonneau, A.: A multicriteria climatic classification system for grape-growing regions worldwide, Agr. Forest Meteorol., 124, 81-97, 2004.

Van Leeuwen, G. S.: The Concept of Terroir in Viticulture, Journal of Wine Research, 17, 1-10, 2006. 
Van Leeuwen, C. and Seguin, G.: The Concept of Terroir in Viticulture, Journal of Wine Research, 17, 1-10, 2006.

Van Leeuwen, C., Friant, P., Chone, X., Tregoat, O., Koundouras, S., and Dubourdieu, D.: Influence of climate, soil, and cultivar on terroir, Am. J. Enol. Viticult., 55, 207-217, 2004.

Wilson, J. E.: Terroir: The role of geology, climate, and culture in the making of French wines, University of California Press, Berkeley, 336 pp., 1998.
Winkler, A. J., Cook, A. J., Kliewer, W. M., and Lider, L. A.: General Viticulture, 2nd Edn., Univ. of California Press, California, 710 pp., 1974. 